\title{
The Notion of Age in Organizational Research
}

\author{
Tanja Kosowski ${ }^{1}$
}

Submitted: 28.08.18. Final acceptance: 29.10.18

\section{Abstract}

Purpose: The article critically reflects on the issue of age in workforces in human resource management and related fields. Age is widely used by scholars to denote the entire workforce of a company. The vast remit of this concept has resulted in many ongoing debates, such as young vs. old employees, mature employees, the aging workforce, as well as various stereotypes pertaining to age in academic research.

Methodology: The paper reviews recent academic literature: articles from peer-reviewed journals, written in English, and published in 2000-2018. Keywords and elimination criteria are explained in the corresponding section.

Findings: Research in this field shows the use of inhomogeneous groups in accordance to their age, which ultimately threatens to hinder the comparability of undertaken studies in this domain.

Research implications: There exists no clear consensus regarding the age-markers or barriers used to distinguish the workforce of an organization or to form groups of employees of a given age-cluster.

Originality: This text is the first review of studies in the field, in which age has been the main criterion to distinguish workforce. The review encourages dialog among scholars from various disciplines as a way to lessen discrepant categorizations.

Keywords: workforce, age diversity management, chronological age, generational segmentation, systematic literature review

JEL: M12

\footnotetext{
1 Kozminski University

Correspondence address: Kozminski University, Department of Management, 59 Jagiellońska St., 03-301 Warsaw, Poland, e-mail: tkosowski@ kozminski.edu.pl
} 


\section{Introduction}

As a result of increasing competitiveness in the labor market, age is becoming an important field of studies among human resource management scholars, both on the local and global scale (Taranko, 2009). The issue of workforce continues to gain importance in the twenty-first century, having undergone scrutiny from various angles. Currently, there exist ever-evolving debates around ageing, skill shortage, diversity, and ageism in organizational research, as well as labor market participation, unemployment, prolongation of working life, and bridge employment in various policy-related discussions. When investigating this subject, scholars tend to focus on demographic groups ranging from 15 to 75 years of age, depending on the case.

The investigation of workforce-related issues remains at the forefront of the ongoing research agenda. However, there is no clear consensus on how to draw a line between the varying demographic groups in the workforce. Moreover, various voices called for a closer definition of age divisions in the workplace, as the current lack of a priori consensus on demographic groups presents a common problem that hinders comparability (McCharthy et al., 2014). Therefore, discussions that evolve around age and labor market are often hampered by the difficulty to define an exact group when referring to workforce in organizational terms. There is no consensus about age diversity, stereotyping, and moving from mid-career to mature-aged employees. Similarly, neither are there any common thresholds for discussions on youth unemployment, labor market participation of mature-aged employees, and the ageing of the workforce as a whole (Kooij et al., 2008; Trochimiuk, 2014).

This article critically analyzes the issue of age in organizational research. Many scholars apply age categorizations to denote the entire workforce of a company. However, there exists no clear consensus regarding the age-markers or barriers that distinguishes the workforce of an organization or forms groups of employees that belong to a given age-cluster. This paper presents the first review of studies in this field, in which age is the main criteria for categorizing workforce. This text identifies and introduces prevalent age categorization concepts and offers guidance for future research studies. It will enforce comparability and transparency of research studies drawn on research samples selected with age-metrics. 


\section{Methodology}

Age categories used in research studies are complex while their scholarly interpretations vary. For an overview of existing research studies, the author employed several keywords in the literature search process. A useful feedback in the identification of keywords relates to abstracts and used subject keywords. The constant comparison of keywords allowed for the identification of the most commonly used phrases. The author conducted a systematic literature review following Czakon (2011) and using the Scopus database.

As previously mentioned, organizational research seems to be rather unclear in the use of age categories. For this reason, the author resorted to a combination of several keywords in the four-stage literature search. Further analysis of abstracts, titles, or full texts in uncertain cases allowed for the identification of relevant publications. The snowballing technique was used to expand the base of selected articles conditionally, if there appeared cross-references to age categorizations in related articles. The Figure 1 illustrates the rationale of the literature search and identification process.

Figure 1. The rationale of literature query process

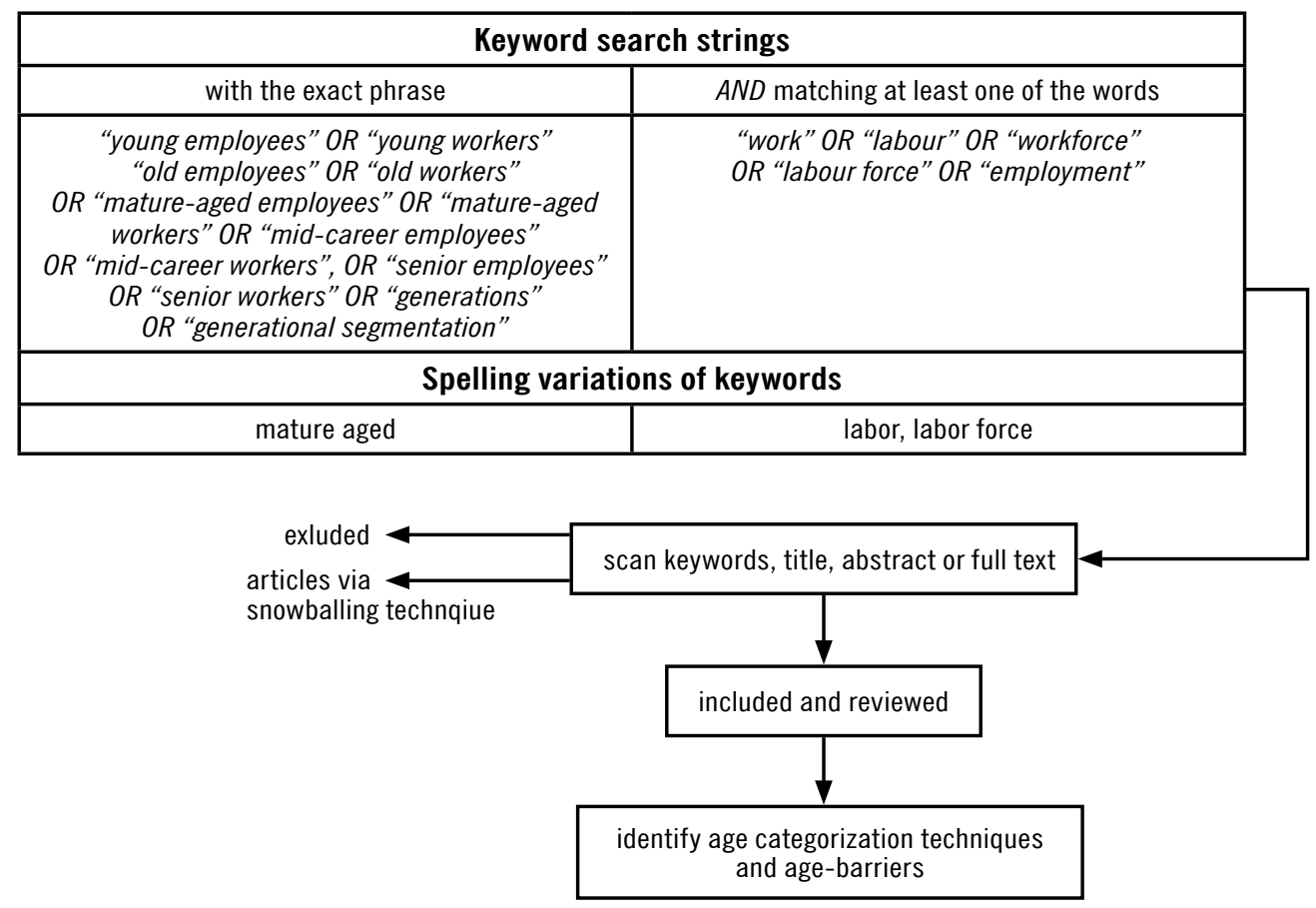

Source: own elaboration. 
The list of articles produced by the initial search was improved by eliminating articles that did not contain the aforementioned keywords and were published outside of Europe. The successive screening of titles identified the publications that consider age in an organizational context. The final list of articles contained 144 articles. After the screening of abstracts, the author selected 64 articles for review. At this stage, no further method of conceptualization of the remaining publications appeared viable. Finally, the author added 13 more articles to the final review list via snowballing technique.

\section{Typologies of Age}

We may approach the notion of age from a variety of different perspectives. Table 1 gathers the conceptualization methods used in the selected articles. Despite the fact that chronological age may be the most frequently-used indicator to determine age in workforce debates and research, there remains an academic opinion that this may not be a sufficient variable. Hence, various additional theories regarding this subject have co-evolved and co-existed over time. Models for age conceptualization stem either from age typology by Stern and Doverspike (1989) or Laslett (1996), or generational segmentation. Various scholarly voices (Laslett, 1996; Vaahtio, 2006) state that age in the labor force is a combination of various age types under the consideration of other environmental factors. Therefore, Laslett (1996) argues for a dimension of age in the labor market as a mixture of personal and environmental factors.

Table 1. Article distribution in age conceptualization methods

\section{Age typology}

\section{Criterion:}

Chronological age: 50 articles

Social perception of age: 1 article

Self-perception of age: 1 article

Life-span age: 1 article

Without age metric: 2 articles

\section{Generational segmentation}

Total

55 articles

22 articles

Source: own elaboration. 


\section{Stern and Doverspike}

Stern and Doverspike (1989) argue that age is a sum of personal factors and circumstances that differentiate between five various dimensions to determine the "actual" age of an individual. In their opinion, we must account for all variables to determine one's age, as chronological age alone is not inexplicit.

Simply put, chronological age reflects an individual's calendar age, functional age signifies workplace performance, and psychological age is the self- and social perception of one's number of years. Stern and Doverspite (1989) refer to the dimension that takes into consideration one's career stage as organizational age. Moreover, the notion of life-span age underlines the idea that age is a fluid concept, as the environment of a person may change over time.

1. Chronological age: a person's actual calendar age.

2. Functional/performance-based age: it recognizes performance and different levels of health, capacity, performance, and cognitive abilities as they vary throughout a worker's life.

3. Psychological/subjective age: a combination of self and social perception of one's age.

4. Organizational age: a combination of one's career stage, skillset, and prevailing age norms in a given organization.

5. Life-span age: a combination of all of the above with the account of individual's behavioral changes.

Cleveland and Shore (1992) criticize this model for the lack of clear indicators or age barriers to differentiate between the five dimensions. In their opinion, the five dimensions exert a significant impact on the wide range of variables that pertain to work and employment. Therefore, Cleveland and Shore suggest a two-dimensional approach that differentiates between the person-based view and the context-based view. However, building on Lange et al. (2006), Schalk et al. (2010) agree that Stern and Doverspike's conceptualization may prove insightful and practical in terms of the workforce, hence Schalk et al. suggest a number of indicators for the five dimensions. In 2014, McCharthy et al. build upon their suggestions to study 1,200 organizations and portray how age varies across those five dimensions. 
Figure 2. The possible indicators for Stern's and Doverspike's model

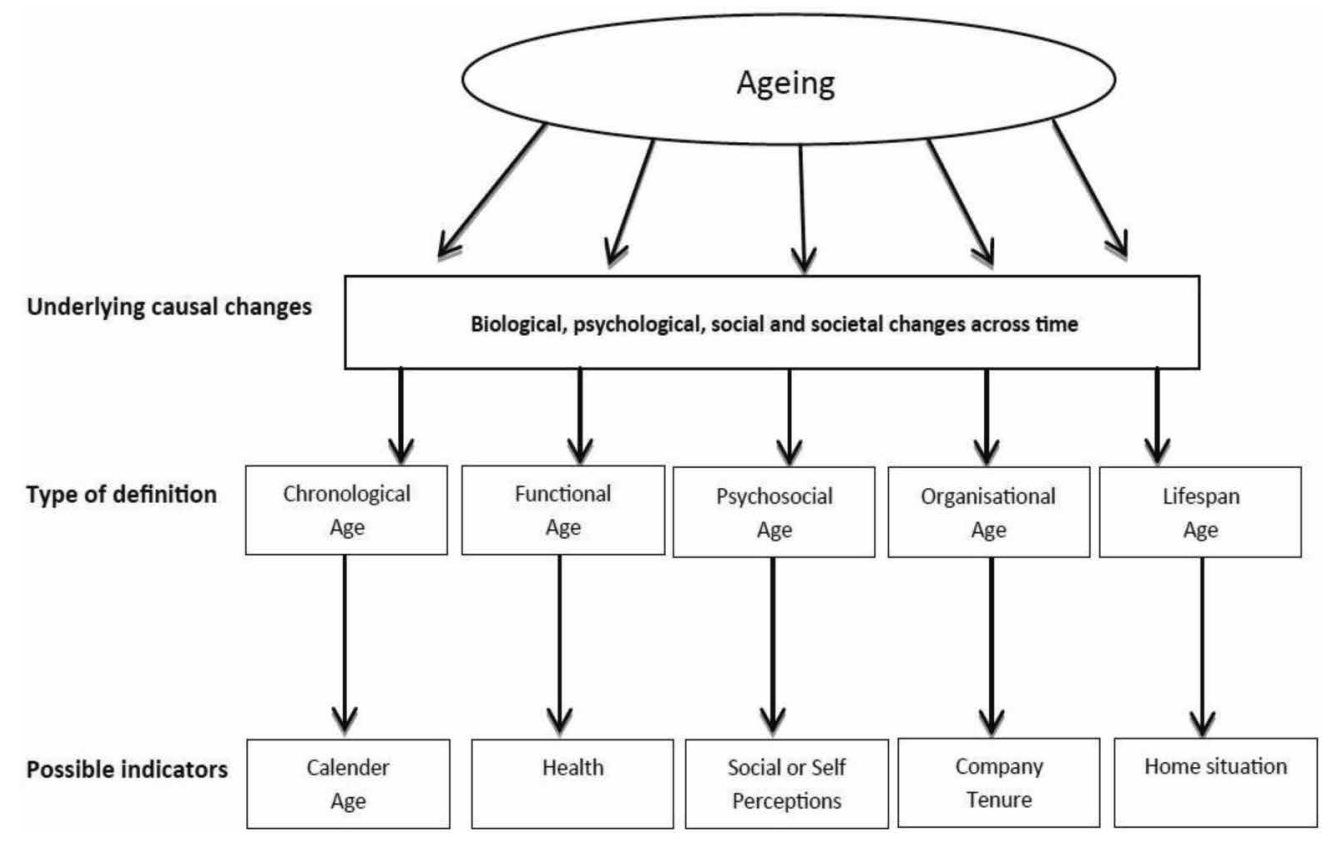

Source: cf. McCarthy et al. (2014, p. 378).

\section{Peter Laslett}

According to Peter Laslett (1996), there are four types of age. The first - biological age - corresponds to chronological age. The other three categories - personal, social, and subjective - refer to the idea of life phase that removes them from the perception of one's age. Social age is devoid of perceptions and relies on social groups in an individual's environment, such as friends, family, colleagues, and authorities. Finally, personal age combines the idea of life phase with one's self-perception, while subjective age is free from the idea of life phase and relies only on one's innermost self-perception about age.

Nonetheless, scholars agree with the fact that age in the work-setting is a far more complex issue. Besides, age categories in organizational research vary greatly. For example, research often defines young employees in an extremely imprecise manner, ranging from anywhere between 16 to 40 years old (Rabl and Scroggins, 2010). Moreover, such a broad spectrum of chronological age may hinder research attempts, as it might overlap with the definition of a younger, middle-aged, or even senior employees in other studies. The age barrier for senior employees in studies fluctuates similarly: 
from 50, 40, or in extreme cases, even from the age of 30 years (Turek and Perek-Bialas, 2013; WEF, 2016). Moreover, if one defines an age span of a group as more than 30 years, its members will be most likely driven by differentiating working needs, expectations, and values as their peers. Similarly, some research lacks the presence of any age metric and simply compares "young employees" to "mid-career" or "senior employees." Studies that utilize such discourse frequently address issues pertaining to the performance, age discrimination, or well-being of employee groups (Cheung, Kam and Ngan, 2011; Furunes and Mykletun, 2010; James, McKechnie, Swanberg and Besen, 2013; Conen, van Dalen and Henkens, 2012).

\section{Generational Segmentation}

The second conceptualization of age stems from the field of marketing research. Generational segmentation is an age-related model, which groups individuals by similar characteristics and traits (Maison, 2014). The term "generation" is often broadly defined and refers to a "group that shares birth years, age, location and significant life events at critical development stages" (Kupperschmidt, 2000). This segmentation model classifies different generations based on the year of birth, from 1946 to the present. The most frequent approach here is to categorize generations into four different groups: Veterans, Baby Boomers, Generation X, and Generation Y. The field that especially values generational segmentation is longitudinal studies, which outline the similarities and differences between different generations (Loughlin and Barling, 2001, pp. 543-558; Parry and Urwin, 2011, pp. 79-96; Twenge, Campbell, Hoffman, and Lance, 2010, pp. 201-210).

Most scholars believe that generational differences impact various aspects in the field of human resources, including recruitment, career development, coaching and training, incentivization, working arrangements, and management style. However, studies especially apply generational segmentation to explore the different work values between different generations. Research suggests that there are certain prevailing norms and patterns among generations that impact the work setting (Smola and Sutton, 2002). Generational values tend to be immutable, as we learn them during the course of our lives and keep them relatively unchanged. Therefore, the general consensus proposes that representatives of the various generational groups ought to be managed differently. 
Table 2. The overview of age barriers in generational segmentation

\begin{tabular}{|c|c|c|c|c|c|}
\hline Article & Veterans & $\begin{array}{c}\text { Baby } \\
\text { Boomers }\end{array}$ & Generation X & Generation Y & Others \\
\hline Rai (2012) & & & & 1982-2000 & \\
\hline $\begin{array}{l}\text { Appelbaum et al. } \\
\text { (2005) }\end{array}$ & & $\begin{array}{l}1947-1966 / \\
1943-1960\end{array}$ & 1961-1981 & & \\
\hline $\begin{array}{l}\text { Broadbridge et al. } \\
\text { (2007) }\end{array}$ & & & & 1977-1994 & \\
\hline $\begin{array}{l}\text { Cennamo } \\
\text { and Garndner } \\
\text { (2008) }\end{array}$ & & 1946-1961 & 1962-1979 & $1980-$ & \\
\hline Kim et al. (2008) & & & & 1977-1994 & \\
\hline $\begin{array}{l}\text { Dziewanowska } \\
\text { (2016) }\end{array}$ & & & & $\begin{array}{l}\text { not at all } \\
\text { specified } \\
\text { (students) }\end{array}$ & \\
\hline $\begin{array}{l}\text { Lippmann } \\
\text { (2008) }\end{array}$ & -1945 & 1946-1964 & 1965- & & $\begin{array}{l}1946-1955 \text { (early baby } \\
\text { boomers) behave } \\
\text { different than } 1956-64 \\
\text { (late baby boomers) }\end{array}$ \\
\hline $\begin{array}{l}\text { Twenge and } \\
\text { Campbell } \\
\text { (2008) }\end{array}$ & & & 1961-1981 & 1982-1999 & \\
\hline $\begin{array}{l}\text { Sessa et al. } \\
\text { (2007) }\end{array}$ & & 1940-1964 & 1960-1982 & $\begin{array}{l}\text { 1982/1983 } \\
\text { - no agreed } \\
\text { cut-off date }\end{array}$ & $\begin{array}{l}\text { 1909-1933 WWIIs, } \\
\text { 1934-1945 Swingers/ } \\
\text { Silents/Veterans, } \\
\text { born before the 1940s } \\
\text { Traditionalists; also } \\
\text { diff. between early and } \\
\text { late baby boomers }\end{array}$ \\
\hline $\begin{array}{l}\text { Smola } \\
\text { and Sutton } \\
\text { (2002) }\end{array}$ & & 1940-1964 & 1960-1975 & 1979-1994 & $\begin{array}{l}\text { also says no agreement } \\
\text { on birth year in cohorts }\end{array}$ \\
\hline $\begin{array}{l}\text { Terjesen } \\
\text { and Freeman } \\
\text { (2007) }\end{array}$ & & & & $\begin{array}{l}\text { not at all } \\
\text { specified } \\
\text { (students) }\end{array}$ & \\
\hline $\begin{array}{l}\text { Twenge et al. } \\
\text { (2010) }\end{array}$ & 1925-1945 & 1946-1964 & 1965-1981 & 1982-1999 & \\
\hline $\begin{array}{l}\text { Wong et al. } \\
\text { (2008) }\end{array}$ & 1924-1944 & 1945-1964 & 1965-1981 & 1982-2000 & \\
\hline
\end{tabular}

Source: own elaboration. 
However, the cause for scholarly concern resides in the fact that there exists an uneven approach to generational segmentation. If one were to open an HR management magazine, a business consultancy publication, or even a peer-reviewed article, one would rarely find a clear indication of how to define a specific generation. Moreover, another issue that creates academic discrepancy is the fact these groups do not possess a clear-cut definition: the year of birth often varies between studies and reports. On top of this, different sociological experiences and historical events mean that the systematic evaluation of generational differences proves both challenging and rare. However, Lyons, Duxbury, and Higgins (2007) strongly support this standpoint by claiming that despite the popularity of this topic and its usage, there is relatively little academic work to confirm or refute popular stereotypes.

Parry and Urwin (2011) applied generational segmentation to prepare an extensive review of generational differences in work values. They conduct a literature review on the usage and practicality of generational segmentation when evidencing generational differences in work values. The summary of Parry and Urwin (2011) about the different interpretations of generations was taken and extended to show the variety of co-existing and co-evolving approaches for generational segmentation. Table 2 makes evident that there exists no clear-cut point for the year of birth, if we refer to a certain generation in organizational research.

\section{Discussion}

Discussions about age in organizational research vaguely differentiate between age cohorts. Still, there is no clear definition or segmentation model for general use. As there seems to exist no consensus either on clear age-markers or segmentation models, we cannot compare research and discussions in the field of organizational research, not to mention social research. As age cohorts are incomparable, a solid discussion, generalization, and inferences may not be genuine on the basis of this research.

There are no clear rules for the use of age typologies or generational segmentation in organizational research. However, we observe a trend for the topics in which predominantly apply these categorizations. Age typologies usually discuss such topics as workforce participation, performance, discrimination, and training and development. Whereas generational segmentation or age typologies with no specific age metric focus on topics such as work-values, well-being, and employee motivation. 
However, generational segmentation in the field of organizational research does not constitute an appropriate segmentation tool for several reasons. The strongest argument against it is the excessive number of people called a specific generation. To form a generation, segmentation tools group individuals from age ranges of 15 to 30 years. Therefore, individuals included in such cohorts create heterogeneous rather than homogeneous groups. Therefore, we should consider that these individuals greatly vary already within a group, when we scrutinize their specific characteristics and body of thoughts. Moreover, there is no research that clearly distinguishes generations according to their specific characteristics and mindsets, which would help to properly define a generation and separate it from other groups. As illustrated by Table 1 chronological age seems to be a popular and widely-used indicator when it comes to discussions regarding age.

However, many scholars foreground the various disadvantages of chronological age. For example, they question chronological age as it tells us little about individuals, as it is possible to have children even at a high age or achieve multiple career peaks. Furthermore, due to the flexibility and diversity of today's lifestyles, chronological age seems to be only an elastic indicator to describe a person's life stage. This holds especially true for high-age groups, as chronological age may prove somewhat erroneous due to the increasing heterogeneity in the process of ageing. Moreover, the notion of age is affected by other various indicators. The logical starting point is the socio-economic research in the European Union. The Eurobarometer (European Commission, 2012), an institution that surveys and captures the social opinion in the EU member states, conducted the Active Ageing survey in 2011, which captured the perception of what it means to be "young" and "old" in all 27 EU member states. In Slovakia, an "older worker" is somebody above 57 years of age, whereas in the Netherlands only people over 70 are considered to be "older employees." As these two countries show the extreme opinions about their perception of "young" and "old," this paper uses Netherlands and Slovakia as exemplary countries in the below elaboration of the factors that impact the perception and interpretation of age.

Such variations may cause significant differences in studies conducted on a national level and can, therefore, hinder comparability among the EU member states. For example, someone is to be still young at a higher age than in countries with an earlier entrance into the workforce in the countries with a high percentage of tertiary education (Netherlands $32 \%^{2}$; Slovakia $10 \%{ }^{3}$ ), hence also a later entrance into the workforce. Correspondingly, in countries with a high life expectancy, an old person is considered to start

\footnotetext{
$\%$ of the population holding a university degree (OECD, 2014a).

$\%$ of the population holding a university degree (OECD, 2014b).
} 
at a higher age than in countries with a relatively low life expectancy (Netherlands: 81.6 years; Slovakia: 77.4 years). ${ }^{4}$ The same is true, if we take into account the average age of the society (Netherlands: 42.6 years; Slovakia: 40.5 years). ${ }^{5}$ For older societies, the barrier to consider a person old is higher than that in relatively younger societies.

To grant comparability and transparency, this review suggests a two-sided approach. In the field of organizational research, topics pertaining to the micro-level (one particular organization) or meso-level (several organizations) are of prior interest to scholars. Research on the meso-level engages in such issues as organizational strategy or personnel strategy, so that it frequently uses data coming from surveys distributed among several organizations. On the other hand, research on the micro-level concentrates on such issues as performance, employee behavior, and work conditions, so that it applies rather subjective data coming from employee surveys. These factors appear useful for research studies on the meso- and micro-level of an organization. However, when researching the micro-level of an organization, they should be slightly different. On a micro-level, tacit assumptions prevail, that is attitudes and characteristics assigned by individuals to age cohorts. These tacit assumptions are also known as stereotypes. Stereotypes are existing from a positive and negative character and prove to have a strong influence on the micro-level (Poulston and Jenkins, 2013; Conen et al., 2011; Cheung et al., 2010). Therefore, research studies that focus on the micro-level should additionally stress and capture the stereotyping patterns of participants.

\section{The Factors Influencing the Interpretation of Age}

Therefore, when writing about the notion of age - in an organizational context or policy discussions - the background information about the group in the focus of the discussion is crucial for further interpretation. Overall, there seem to be several factors that frame the tendency of discussions on age:

1) the overall life expectancy in a given target population, 2) the age in which the members of a given target population usually enter the workforce, 3) the culture and corresponding social interpretation of young and old (micro-level: cultural interpretation of young and old in a given organization), 4) the overall retirement age in a society, 5) the average age or age median in a given target population (micro-level: average age or median age in a given organization), and 6) the age of the participants in a study. Without a clear analysis and transcription of these factors, further evaluation of results may prove dubious and debatable.

\footnotetext{
Sourced from the database: worldhealthrankings.

Median age of society, sourced from the database: indexmundi.
} 
Figure 3. Factors which frame the discussion on age

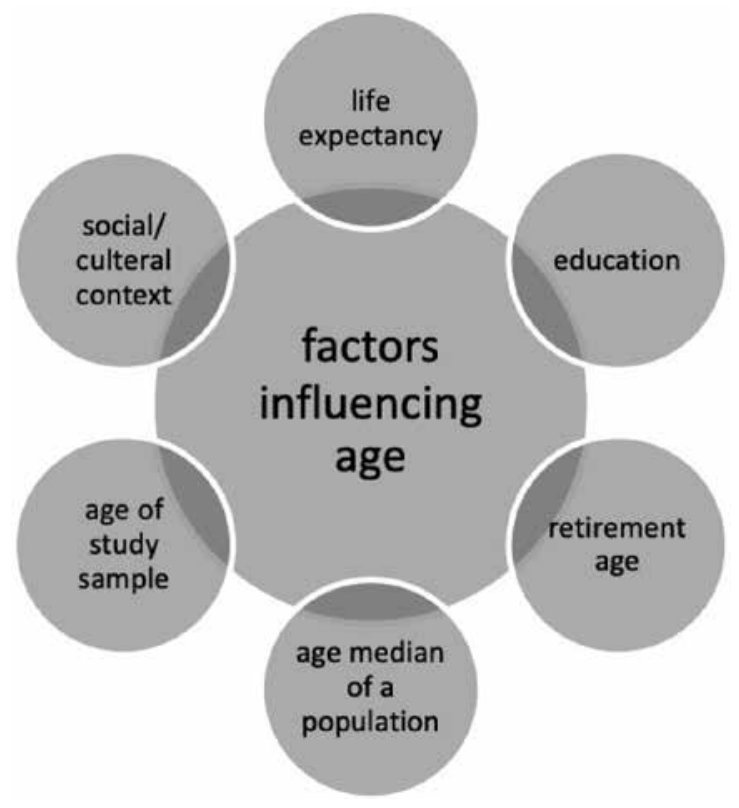

Source: own elaboration.

\section{Conclusions}

This article focuses on the notion of age in organizational research, especially on the methods of how age is determined and measured in current research studies. This literature review seeks a consensus for the conceptualization of age, presents the frequently used age conceptualization methods, and gives guidance for further research studies which use age as the main criterion. Indeed, there is no consensus in the literature on how to group employees into different age-clusters (McCharthy et al., 2014; Kooij et al., 2008). Therefore, in this part, the findings of this article agree with the literature.

As mentioned above, the lack of consensus may hinder the comparability and reproducibility of research studies. This article highlights several most frequently used age conceptualization methods. Age typologies mostly rest on the use of chronological age as an indicator. Despite several drawbacks, the popularity of chronological age may stem from its exact determinability and for simplification. On the other hand, generational segmentation shows discrepancies even in the definition of a generation. Overall, these inconsistencies may affect research conducted on the micro- and meso-level of an organization. 
Thus, for research conducted on the meso- and micro-level of an organization, this article suggests reporting further six factors in addition to the main age indicator: life expectancy, duration of education, social/organizational interpretation of age, retirement age, median age of the population/organization, and age distribution in the research sample. Moreover, at the micro-level of an organization, the results may be further biased by the stereotypes of research participants. Many research studies reveal prevailing age stereotypes, which offers a valid point of reference (Poulston and Jenkins, 2013; Conen et al., 2011; Cheung et al., 2010). The aforementioned factors present solutions for an increased level of critical understanding for the interpretation and comprehension of results drawn on a specific research sample selected on the criterion of age, thus improving comparability and transparency.

\section{References}

Czakon, W. (2011). Metodyka systematycznego przeglądu literatury. Przegląd Organizacji, 3: 57-61. Cennamo, L. and Gardner, D. (2008). Generational differences in work values, outcomes and person-organisation values fit. Journal of Managerial Psychology, 23: 891-906, http://dx.doi.org/10.1108/02683940810904385

Cheung, C.K., Kam, P.K. and Ngan, R.M.H. (2012). Age discrimination in the labor market from the perspective of employers and older workers. International Social Work, 54(1): 118-136, http://doi.org/10.1177/002810372368

Conen, W.S., van Dalen, H.P. and Henkens, K. (2012). Ageing and employers‘ perceptions of labor costs and productivity: A survey among European employers. International Journal of Manpower, 33(6): 629-647, http://doi.org/10.1108/01437721211261796

Conen, W.S., Henkens, K. and Schippers, J.J. (2011). Are employers changing their behavior toward older workers? An analysis of employers' surveys 2000-2009. Journal of Aging \& Social Policy, 23: 141-158, http://doi.org/10.1080/08959420.2011.551612

Cleveland, J. and Shore, L. (1992). Self- and supervisory perspectives on age and work attitudes and performance. Journal of Applied Psychology, 77(4): 469-484, http://dx.doi.org/10.1037/0021-9010.77.4.469

European Commission (2012). Active Ageing. Special Eurobarometer 378, Brussels, http://ec.europa.eu/commfrontoffice/publicopinion/index.cfm/Survey/index\#p=1\&yearFrom $=1974 \&$ yearTo $=2012$, accessed 20/08/2018.

Furunes, T. and Mykletun, R.J. (2010). "Age discrimination in the workplace: Validation of the Nordic Age Discrimination Scale (NADS). Scandinavian Journal of Psychology, 51(1): 23-30, http://doi.org/10.1111/j.1467-9450.2009.00738.x

Indexmundi, https://www.indexmundi.com/netherlands/median_age.html (18.10.2018).

James, J.B., McKechnie, S., Swanberg, J. and Besen, E. (2013). Exploring the workplace impact of intentional/unintentional age discrimination. Journal of Managerial Psychology, 28(7): 907-927, http://doi.org/10.1108/JMP-06-2013-0179

Kooij, D., De Lange, A.H., Jansen, P.G.W., Kanfer, R. and Dikkers, J.S.E. (2011). Age and work-related motives: Results of a meta-analysis. Journal of Organizational Behavior, 32(2): 197-225,

http://dx.doi.org/10.1002/job.665 
Kupperschmidt, B. (2000). Multigeneration Employees: Strategies for Effective Management. Health Care Manager, 19(1): 65-76, http://dx.doi.org/10.1097/00126450-200019010-00011

Lange, A.H. de, Taris, T.W., Jansen, P.G.W., Smulders, P., Houtman, I.L.D. and Kompier, M.A.J. (2006). Age as a factor in the relation between work and mental health: results from the longitudinal TAS study. In: J. Houdmont and S. McIntyre (eds). Occupational Health Psychology: European Perspectives on Research, Education and Practice, 1: 21-45, ISMAI Publications, Maia, Portugal, http://dx.doi.org/10.1002/9780470661550

Laslett, P. (1996). A Fresh Map of Life (2nd edition). Macmillan Press, London, UK, http://dx.doi.org/10.1007/978-1-349-24615-1

Loughlin, C. and Barling, J. (2001). Young workers' work values, attitudes, and behaviours. Journal of Occupational and Organizational Psychology, 74(4): 543-558, http://dx.doi.org/10.1348/096317901167514

Lyons, S., Duxbury, L. and Higgins, C. (2007). An empirical assessment of generational differences in basic human values. Psychological Reports, 39, http://dx.doi.org/10.2466/PR0.101.6.339-352

Maison, D. (2014). Values and Lifestyle Segmentation of Poles 55+ and Its Implications for Consumers' Attitudes and Behaviour. Journal of Management and Business Administration. Central Europe, 22(4): 78-94, https://dx.doi.org/10.7206/mba.ce.2084-3356.121

McCarthy, J., Heraty, N. and Cross, C. (2014). Who is considered an 'older worker'? Extending our conceptualisation of 'older' from an organisational decision maker perspective. Human Resource Management Journal, 24(4): 374-393, http://dx.doi.org/10.1111/1748-8583.12041

OECD (2014a). Education at a glance 2014, http://www.oecd.org/education/Netherlands-EAG2014-Country-Note.pdf (18.10.2018).

OECD (2014a). Education at a glance 2014, http://www.oecd.org/education/Slovak\%20Republic-EAG2014-Country-Note.pdf (18.10.2018).

Parry, E. and Urwin, P. (2011). Generational Differences in Work Values: A Review of Theory and Evidence. International Journal of Management Reviews, 13(1): 79-96, http://dx.doi.org/10.1111/j.1468-2370.2010.00285.x

Poulston, J. and Jenkins, A. (2013). The Persistent Paradigm: Older Worker Stereotypes in the New Zealand Hotel Industry. Journal of Human Resources in Hospitality \& Tourism, 12: 1-25, http://doi.org/10.1080/15332845.2013.723252

Schalk, R., van Veldhoven, M., de Lange, A.H., De Witte, H., Kraus, K., Stamov-Roßnagel, C., Tordera, N., van der Heijden, B., Zappalà, S., Matthijs, B., Claes, R., Crego, A., Dorenbosch, L., de Jonge, J., Desmette, D., Gellert, F., Hansez, I., Iller, C., Kooij, D., Kuipers, B., Linkola, P., van den Broeck, A., van der Schoot, E. and Zacher, H. (2010). Moving European research on work and ageing forward: overview and agenda. European Journal of Work and Organisational Psychology, 19(1): 76-101, http://dx.doi.org/10.1080/13594320802674629

Sterns, H.L. and Doverspike, D. (1989). Aging and the retraining and learning process in organisations. In: I. Goldstein and R. Katzel (eds). Training and Development in Work Organisations. Jossey-Bass, San Francisco, CA, United States, http://dx.doi.org/10.1146/annurev.ps.43.020192.00215

Taranko, T. (2009). The impact of population ageing on the life insurance market in Poland. Journal of Management and Business Administration. Central Europe, 17(1): 75-88.

Trochimiuk, R. (2014). Professional Development of Older Employees in Small and Medium Enterprises. Journal of Management and Business Administration. Central Europe, 23(1): 79-94, http://dx.doi.org/10.7206/mba.ce.2084-3356.135

Turek, K. and Perek-Bialas, J. (2013). The role of employers opinions about skills and productivity of older workers: example of Poland. Employee Relations, 35(6): 648-664,

http://dx.doi.org/10.1108/ER-04-2013 
Vaahtio, E.L. (2006). Avaa ikälukot. Vapaudu johtamaan. Edita Prima Oy, Helsinki, Finland.

World Economic Forum (WEF) (2016). Shaping the Global Agenda on Ageing: Meeting the Needs of Cognitive Decline. REF 290716,

http://www3.weforum.org/docs/WEF_Meeting_Needs_Cognitive_Decline_070916.pdf (28/08/2018).

World Health Rankins, https://www.worldlifeexpectancy.com/netherlands-life-expectancy (18.10.2018).

\section{Generational Segmentation}

Appelbaum, S., Serena, M. and Shapiro, B. (2005). Generation X and the Boomers: an analysis of realities and myths. Management Research News, 28, 1-33,

http://dx.doi.org/10.1108/01409170510784751

Broadbridge, A., Maxwell, G. and Ogden, S. (2007). Experiences, perceptions and expectations of retail employment for Generation Y. Career Development International, 12: 523-544, http://dx.doi.org/10.1108/13620430710822001

Cennamo, L. and Gardner, D. (2008). Generational differences in work values, outcomes and person-organisation values fit. Journal of Managerial Psychology, 23: 891-906, http://dx.doi.org/10.1108/02683940810904385

Dziewanowska, K., Pearce, A. and Zupan, N. (2016). Generation Y’s expectations of their future employment relationships pose a challenge for their employees. Journal of Human Resource Management, 19(1): 1-12.

Kim, H., Knight, D.K. and Crutsinger, C. (2008). Generation Y employees’ retail work experience: The mediating effect of job characteristics. Journal of Business Research, 62: 548-556, http://dx.doi.org/10.1016/j.jbusres.2008.06.014

Lippmann, S. (2008). Rethinking risk in the new economy: age and cohort effects on unemployment and reemployment. Human Relations, 61: 1259-1292, https://doi.org/10.1177/0018726708094912

Rai, S. (2012). Engaging young employees (Gen Y) in a social media dominated world - Review and Retrospection. Social and Behavioral Sciences, 37: 257-266, http://dx.doi.org/10.1108/0956423131132698

Sessa, V., Kabacoff, R., Deal, J. and Brown, H. (2007). Generational differences in leader values and leadership behaviours. Psychologist-Manager Journal, 10: 47-74, doi: http://dx.doi.org/10.1080/10887150709336612

Smola, K. and Sutton, C. (2002). Generational differences: revisiting generational work values for the new millennium. Journal of Organizational Behavior, 23(4): 363-382, http://dx.doi.org/10.1002/job.147

Terjesen, S., Vinnicombe, S. and Freeman, C. (2007). Attracting Generation Y graduates: organisational attributes, likelihood to apply and sex differences. Career Development International, 12: 504-522, http://dx.doi.org/10.1108/13620430710821994

Twenge, J.M., Campbell, S.M., Hoffman, B.J. and Lance, C.E. (2010). Generational Differences in Work Values: Leisure and Extrinsic Values Increasing, Social and Intrinsic Values Decreasing. Journal of Management, 36(5): 1117-1142, http://dx.doi.org/10.1177/0149206309352246

Wong, M., Gardiner, E., Lange, W. and Couon, L. (2008). Generational differences in personality and motivation: do they exist and what are the implications for the workplace? Journal of Managerial Psychology, 23: 878-890, http://dx.doi.org/10.1108/02683940810904376 